\title{
Diyarbakır'da Pamuk Alanlarından Toplanan Tetranychus urticae (Koch) (Acari: Tetranychidae) Popülasyonlarında Abamectin Duyarlılık Düzeyleri ile Esteraz ve GST Enzim İlişkileri
}

\author{
Sibel YORULMAZ SALMAN ${ }^{* 1}$ ㅁ, Emine BAYRAM ÖZATA ${ }^{2}$ \\ 1,2Isparta Uygulamalı Bilimler Üniversitesi, Tarım Bilimleri ve Teknolojileri Fakültesi, Bitki Koruma Bölümü, \\ 32260, Isparta, Türkiye
}

(Alınış / Received: 30.04.2019, Kabul / Accepted: 03.09.2019, Online Yayınlanma/ Published Online: 30.12.2019)

Anahtar Kelimeler
Tetranychus urticae,
Abamectin,
Direnç,
Diyarbakır,
Esteraz

Anahtar Kelimeler Tetranychus urticae, Direnç, Esteraz

\begin{abstract}
Özet: Tetranychs urticae pamuk alanlarında önemli zararlara neden olan bir akar türüdür. Çalışmada ülkemizde önemli pamuk üretim alanlarından birisi olan Diyarbakır ili ve ilçelerinden toplanan15 adet Tetranycus urticae popülasyonunda abamectin duyarlılık düzeyleri ile esteraz ve GST enzim ilişkileri çalışılmıştır Çalışma sonucunda abamectin için Bismil 1, Bismil 2, Bismil 3, Çınar 1, Çınar 2, Çınar 3, Kayapınar 1, Kayapınar 2, Ergani, Eğil, Sur 1, Sur 2, Yenișehir 1, Yenişehir 2 ve Yenișehir 3 popülasyonları için direnç oranları sırasıyla 289, 267, 342, 190, 269, 206, 132, 97, 116, 57, 204, 75, 204, 164 ve 135 kat olarak belirlenmiştir. Ayrıca aynı popülasyonlar için esteraz enzim ektiviteleri sırasıyla; 2.66, 2.54, 2.82, 2.43, 2.70, 2.33, 2.12, 1.91, 2.12, 1.70, $2.01,2.01,2.65,2.63,2.33$ kat ; GST enzim aktiviteleri ise 1.96, 2.29, 2.50, 1.98, 2.29, 2.71, $2.33,1.33,1.68,1.78,2.34,1.53,2.10,1.75,1.72$ kat olarak belirlenmiştir. . Hassas popülasyonda ise esteraz ve GST enzim aktiviteleri sırasıyla 9.48 ve $3.11 \mathrm{mOD} \mathrm{min}^{-1} \mathrm{mg}$ ${ }^{1}$ olarak bulunmuştur.
\end{abstract}

\section{Abamectin Susceptibility Levels and Esterase and GST Enzyme Relationships in Tetranychus urticae (Koch) (Acari: Tetranychidae) Populations Collected from Cotton Fields in Diyarbakır}

Keywords Tetranychus urticae, Abamectin, Resistance, Diyarbakır, Esterase

\begin{abstract}
Tetranychus urticae is a type of mite that causes significant damage in cotton fields. In this study, abamectin susceptibility levels, esteraz and GST enzyme relationships were studied in 15 Tetranycus urticae populations collected from Diyarbakır province and districts, one of the important cotton production areas in Turkey. The resistance ratios for Bismil 1, Bismil 2, Bismil 3, Cinar 1, Cinar 2, Cinar 3, Kayapinar 1, Kayapinar 2, Ergani, Egil, Sur 1, Sur 2, Yenisehir 1, Yenisehir 2 ve Yenisehir 3 was found to be 289, 267, $342,190,269,206,132,97,116,57,204,75,204,164$ and 135- fold, respectively. Also esterase and GST enzyme activities for the same populations was found to be 2.66, 2.54, $2.82,2.43,2.70,2.33,2.12,1.91,2.12,1.70,2.01,2.01,2.65,2.63,2.33$ and 1.96, 2.29, 2.50, $1.98,2.29,2.71,2.33,1.33,1.68,1.78,2.34,1.53,2.10,1.75,1.72$ fold respectively.The esterase and GST enzyme activities of the susceptible population was found to be 9.48 ve $3.11 \mathrm{mOD} \mathrm{min}^{-1} \mathrm{mg}^{-1}$, respectively.
\end{abstract}

\section{Giriş}

Pamuk; lifi, tohumu ve küspesi ile çeşitli alanlarda kullanılabilen yetiştiricilik açısından önemli bir endüstriyel bitkidir [1]. Türkiye dünyada pamuk üretimi açısından incelendiğinde 462 bin hektar üretim alanı ile dokuzuncu sırada yer almaktadır [2]. Ülkemizde ise en fazla pamuk ekim alanı ve üretimi Güneydoğu Anadolu Bölgesinde yer almaktadır. Güneydoğu Anadolu Bölgesindeki pamuk üretiminin büyük bir kısmı ise toprak ve iklim şartlarının uygun olması nedeniyle Diyarbakır ilinde yapılmaktadır. Üreticiler pamuk üretim sezonu boyunca birçok zararlı ile mücadele etmek zorunda kalmaktadır. Bu zararlılar içerisinde pamukta önemli derecede ekonomik kayba neden olan Tetranychus urticae Koch (Acari: Tetranychidae) ilk sıralarda yer almaktadır. Tetranychus urticae'nin pamuk bitkisindeki zararı stomaların iletkenliğini ve transprasyonunu büyük ölçüde düşürerek fotosentezin azalmasına neden olmaktadır [3]. Pamuk üreticileri çoğunlukla iki 
noktalı kırmızıörümcek ile mücadele insektisit ve akarisit uygulamalı yapmaktadır. Ancak zararlının çok fazla sayıda döl vermesi ve hızlı üremesi nedeniyle birkaç uygulamadan sonra kimyasallara karşı direnç gelişimi hızlanmaktadır. Bir süre sonra ise uygulanan kimyasal dozları zararlı üzerinde etki göstermemeye başlamaktadır.

Abamectin (avermectin B1) Streptomyces avermitilis kökenli akarisidal etkisi bulunan bir biyofermentasyon ürünüdür [4]. $\mathrm{Bu}$ kimyasal ülkemizde 1981 yılında ruhsat almıștır. Ruhsat aldığ tarihten itibaren günümüze kadar içerisinde pamuk da bulunan birçok bitkide zarar yapan T. urticae'nin mücadelesinde geniş alanlarda kullanılmaktadır.

Bu çalışmada Diyarbakır ili pamuk üretim alanlarında zarar yapan T. urticae popülasyonlarında abamectin direncinin incelenmesi amaçlanmıştır. Ayrıca biyokimyasal testlerle direncin esteraz ve GST enzimleriyle olan ilişkisi de ortaya koyulmuştur.

\section{Materyal ve Metot}

\subsection{Tetranychus urticae popülasyonlarının toplanması}

Tetranychus urticae popülasyonları 2017 yılı pamuk üretim sezonunda Diyarbakır ilinde pamuk üretimi yapılan ilçelerden toplanmıştır. Ekim alanı ve üretim miktarları dikkate alınarak Bismil, Çınar ve Yenişehir ilçelerinden 3'er popülasyon, Sur ve Kayapınar ilçelerinden 2'şer popülasyon, Eğil ve Ergani ilçelerinden 1'er popülasyon olmak üzere toplam 15 popülayon toplanmıștır. Survey çalıșmalarında üzerinde kırmızıörümcek bulunan yapraklar toplanarak poşet içerisine konularak etiketlenmiştir. Toplanan örnekler buz kutusu içerisinde ISUBU, Ziraat Fakültesi, Bitki Koruma Bölümü ISUBU, Ziraat Fakültesi, Bitki Koruma Bölümü Akaroloji Laboratuarına getirilmiştir.

\subsection{Tetranychus urticae popülasyonlarının yetiştirilmesi}

Laboratuara getirilen örnekler temiz barbunya bitkileri üzerine aktarılmıştır. Popülasyonların birbirleri ile karışmasını engellemek amacıyla barbunya bitkileri içi su dolu küvetlere yerleştirilmiştir. Karşılaştırma popülasyonu olarak 2001 yılında İngiltere'den getirilerek halen laboratuarda yetiștirilmekte olan hassas popülasyon (GSS) kullanılmıştır. Tüm popülasyonlar $25 \stackrel{\circ}{ } \mathrm{C}$ sıcaklıkta, \% 55 orantılı nem 16:8 saat fotoperiyod koşullarında üretilmiştir.

\subsection{Akarisit}

Çalışmada abamectin etkili maddeye sahip bir akarisit kullanılmıştır (Algamek 1,8 EC, Agrobest Türkiye). $\mathrm{Bu}$ etken maddeye sahip bir akarisitin seçilmesinin nedeni Diyarbakır ili pamuk üretiminde kırmızıörümcek mücadelesinde en yaygın kullanılan etken maddelerden biri olmasıdır.

\subsection{Farklı Tetranychus urticae Popülasyonlarında $\mathrm{LC}_{50}$ değerlerinin belirlenmesi}

Kırmızıörümcek popülasyonlarının $\mathrm{LC}_{50}$ değerlerinin belirlenmesinde Rauch ve Nauen[5] yöntemi kullanılmıştır. Çalışmada her tarla popülasyonu için ön denemeler yapılarak \%95 civarı ölüm sağlayan dozlar ilk doz olarak kullanılmıștır. Belirlenen abamectin dozları saf su içinde hazırlanmıştır. İlk dozdan itibaren kullanılacak son doza kadar çözelitilere \% 50 oranında saf su eklenilerek dozlar hazırlanmıştır. Tabanı nemli olan $9 \mathrm{~cm}$ çapındaki petri içerisine yaklaşık $3 \mathrm{~cm}$ çapındaki barbunya yaprak diskleri yerleştirilmiştir.

Tüm çalışma boyunca abamectin 7 doz ve her dozda 3 tekerrür olacak şekilde kurulmuştur. Kontrol grubu ise abamectin dozu hazırlanırken çözücü olarak kullanılan saf su ile kurulmuştur. Denemelerde her bir petriye $30 \pm 2$ tane dişi birey aktarılmıştır. Abamectin dozları ilaçlama kulesi kullanılarak 100 $\mathrm{kPa}$ basınç altında yaprak yüzeyine $2 \mathrm{~mL}$ sıvı düşecek şekilde püskürtülmüștür.

Abamectinin farklı dozları ile ilaçlanan petriler ilaç damlaları kuruyana kadar bekletilmiștir. Dha sonra ise, $25{ }^{\circ} \mathrm{C}$ sicaklık, \%50 nem ve $16: 8$ saat $(\mathrm{A} / \mathrm{K})$ fotoperiyot koşullarının sağlandığı iklim odasına alınmıştır. Ölü canlı sayımları 24 saat sonra yapılmıştır. Çalışmada, kontroldeki ölümlerin \%10'u geçmesi ve en yüksek dozda \%95'ten az ölüm olması durumunda denemeler tekrar kurulmuştur.

Elde edilen verilerden yararlanarak popülasyonların LC $_{50}$ değerleri POLO probit analizleri programında hesaplanmıștır [6]. Pamuk tarlalarından toplanan kırmızı̈rümcek popülasyonların direnç oranı tarla popülasyonlarının $\mathrm{LC}_{50}$ değerlerinin, hassas popülasyonun (GSS) $\mathrm{LC}_{50}$ değerlerine oranlanmasıyla hesaplanmıştır.

\subsection{Esteraz ve Glutatyon S-transferaz (GST) enzimlerinin belirlenmesi}

Esteraz aktivitesinin belirlenmesinde, $100 \mu \mathrm{L}$ sodyum fosfat buffer (0.1M, pH7.5) hazırlanarak içerisine \% 1 oranında Triton X-100 eklenmiştir. Çözelti içerisine binoküler altında seçilen 20 adet kımızıörümcek dişisi eklenerek homojenize edilmiştir. İçerisinde dişi bireylerin ezildiği çözelti daha sonra $10000 \mathrm{~g}$ ve $+4^{\circ} \mathrm{C}^{\prime}$ de 5 dakika santifirüj edilmiştir. Su ile on kez seyreltilen supernatant ve fosfat buffer'dan $(0.2 \mathrm{M}, \mathrm{pH}$ 6)ayrı ayrı olmak üzere 25'er $\mu$ Lmikropilakanın hücrelerine konulmuștur. Çalışmada kinetik okuma 200mikrolitresubstrat solüsyonunun eklenmesiyle başlatılmıştır. Esteraz enzim aktivitesi kinetik olarak $23^{\circ} \mathrm{C}^{\prime}$ de ve $450 \mathrm{~nm}$ 'de 10 dakika belirlenmiştir. 
Çalışmada ikinci enzim aktivitesi olan GST enziminde ise öncelikle $300 \mu \mathrm{L}$ Tris HCL buffer $(0.05 \mathrm{M}, \mathrm{pH}: 7.5)$ hazırlanmıştır. Bu çözelti içerisinde binoküler altında seçilen otuz adet dişi birey eklenmiştir. Dişi bireyler bu çözelti içerisinde homojenize edilmiştir. Karışım $10000 \mathrm{~g}, \quad+4^{\circ} \mathrm{C}^{\prime}$ de 5 dakika santrifüj edilmiştir. Mikroplaka hücrelerine $100 \mu \mathrm{L}$ supernatant, $100 \mu \mathrm{L}$ 1-kloro-2,4- dinitrobenzen (CDNB) ve $100 \mu \mathrm{L}$ glutathion (GSH) konulmuştur. GST enzimi kinetik olarak $340 \mathrm{~nm}, 25^{\circ} \mathrm{C}$ 'de, 5 dakika belirlenmiştir.

Her enzim seviyesinin belirlenmesinde okumalar dört tekerrürlü yürütülmüştür. Enzim seviyeleri esteraz ve GST enzim aktiviteleri Softmax PRO software bilgisayar programında belirlenmiştir. Enzimlerin toplam protein miktarlarının belirlenmesinde Bradford [7] toplam protein belirleme metodu uygulanmıștır.Popülasyonlar arasındaki esteraz ve GST enzim farlılıklarının belirlenmesinde Duncan çoklu karşılaştırma testi kullanılmıștır.

\section{Bulgular}

\subsection{Farklı Tetranychus urticae Popülasyonlarında LC50 sonuçları}

Diyarbakır ili pamuk üretim alanlarından toplanan popülasyonların abamectin'e karşı LC50 değerleri ve LC50değerine göre direnç oranları Tablo 1'de verilmektedir. Diyarbakır ili pamuk üretim alanından toplanan tüm kırmızıörümcek popülasyonlarında abamectine karşı yüksek oranda direnç belirlenmiștir. Tarla popülasyonlarının LC değerlerinin hassas popülasyonunun LC değerine oranlanması sonucunda, popülasyonlarda 57.32 ile 342.04 kat arasinda abamectin direnci bulunmuştur.Pamuk alanlarından toplanan tüm kırmızı̈rümcek popülasyonlarında abamectinin uzun süredir kullanılması sonucunda yüksek oranda direnç geliştiği düşünülmektedir

Diyarbakır ili pamuk alanlarından toplanan tüm kırmızıörümcek popülasyonlarının probit analizlerinden elde edilen eğim değerleri $>2$ olması sebebiyle popülasyonlarının tamamının homojen yapıda olduğu görülmektedir. Üretim sezonu boyunca fazla sayıda insektisit uygulaması sonucu yoğun seleksiyon baskısına maruz kalan kırmızıörümcek popülasyonlarının hassas bireyleri elenerek, popülasyon dirençli bireyler yönünden daha homojen yapı kazanmıștır.

\subsection{Esteraz ve Glutatyon S-transferaz (GST) enzim sonuçları}

Pamuk tarlalarından toplanan ve hassas T. urticae popülasyonlarında biyokimyasal testlerle elde edilen esteraz enzim aktivitesi sonuçları Tablo 2'de verilmiştir. Pamuk alanlarından toplanan tüm kırmızı̈rümcek popülasyonlarında belirlenen esteraz enzim aktivitesi hassas popülasyona göre daha yüksek bulunmuştur.

Tablo1.Pamuk alanlarından toplanan Tetranychus uticae popülasyonlarında abamectine karşı belirlenen LC50 değerleri ve direnç oranları

\begin{tabular}{|c|c|c|c|c|}
\hline Popülasyon & $\mathrm{n}^{*}$ & Eğim+SE & $\begin{array}{c}\mathrm{LC}_{50}\left(\mathrm{mg} \text { a.i l }{ }^{-1}\right) \\
(\% 95 \mathrm{CL})\end{array}$ & $\mathrm{R}^{* *}$ \\
\hline Bismil 1 & 721 & $3.75 \pm 1.45$ & $\begin{array}{c}278.17 \\
238.37-324.81\end{array}$ & 289.76 \\
\hline Bismil 2 & 719 & $3.79 \pm 0.65$ & $\begin{array}{c}257.02 \\
223.01-291.69\end{array}$ & 267.72 \\
\hline Bismil 3 & 681 & $4.72 \pm 1.06$ & $\begin{array}{c}328.36 \\
287.61-372.65\end{array}$ & 342.04 \\
\hline Çınar 1 & 720 & $2.99 \pm 0.36$ & $\begin{array}{c}182.81 \\
95.25-266.27\end{array}$ & 190.42 \\
\hline Çınar 2 & 690 & $4.69 \pm 0.89$ & $\begin{array}{c}258.98 \\
211.77-310.38\end{array}$ & 269.77 \\
\hline Çınar 3 & 720 & $4.57 \pm 0.75$ & $\begin{array}{c}198.55 \\
119.86-270.13\end{array}$ & 206.82 \\
\hline Kayapınar 1 & 715 & $2.57 \pm 0.26$ & $\begin{array}{c}127.42 \\
96.77-159.58\end{array}$ & 132.72 \\
\hline Kayapınar 2 & 716 & $2.63 \pm 0.25$ & $\begin{array}{c}93.74 \\
74.49-113.51\end{array}$ & 97.64 \\
\hline Ergani & 713 & $5.08 \pm 0.52$ & $\begin{array}{c}112.31 \\
84.49-140.95\end{array}$ & 116.98 \\
\hline Eğil & 682 & $2.62 \pm 0.17$ & $\begin{array}{c}55.03 \\
40.77-73.58\end{array}$ & 57.32 \\
\hline Sur 1 & 710 & $4.46 \pm 0.86$ & $\begin{array}{c}196.08 \\
180.68-211.62\end{array}$ & 204.25 \\
\hline Sur 2 & 717 & $4.36 \pm 0.44$ & $\begin{array}{c}72.80 \\
64.01-80.04\end{array}$ & 75.83 \\
\hline Yenișehir 1 & 712 & $3.36 \pm 0.34$ & $\begin{array}{c}195.84 \\
153.77-240.64\end{array}$ & 204.00 \\
\hline Yenişehir 2 & 720 & $3.68 \pm 0.34$ & $\begin{array}{c}158.13 \\
140.05-176.35\end{array}$ & 164.71 \\
\hline Yenişehir 3 & 678 & $2.85 \pm 0.26$ & $\begin{array}{c}130.31 \\
110.11-165.21\end{array}$ & 135.73 \\
\hline GSS & 720 & $0.25 \pm 1.10$ & $\begin{array}{c}0.96 \\
0.84-1.06\end{array}$ & - \\
\hline
\end{tabular}


*: Birey sayısı ～**: Direnç oranı

Arazi popülasyonları içinde en yüksek esteraz enzim aktivitesi Bismil 3 popülasyonunda $26.78 \mathrm{mOD} \mathrm{min}^{-1}$ $\mathrm{mg}^{-1}$ protein, en düşük esteraz enzim aktivitesi ise Eğil popülasyonunda $16.15 \mathrm{mOD} \mathrm{min}^{-1} \mathrm{mg}^{-1}$ protein olarak tespit edilmiştir.T. urticae tarla popülasyonlarında esteraz enzim aktivitesi oranları 2.82- 1.70 kat arasında değişmiştir.

Tablo2. Tetranychus urticae popülasyonlarının esteraz enzim aktiviteleri

\begin{tabular}{|c|c|c|c|}
\hline Popülasyon & $\mathrm{n}^{*}$ & $\begin{array}{c}\text { Spesifik } \\
\text { aktivite } \\
\text { mOD min }^{-1} \\
\text { mg-1 }^{-1} \text { protein }\end{array}$ & $\mathrm{R} / \mathrm{S}^{* *}$ \\
\hline GSS & 4 & $9.48 \mathrm{c}$ & - \\
\hline Bismil-1 & 4 & $25.25 a$ & 2.66 \\
\hline Bismil-2 & 4 & $24.11 \mathrm{a}$ & 2.54 \\
\hline Bismil-3 & 4 & $26.78 \mathrm{a}$ & 2.82 \\
\hline Çınar-1 & 4 & $23.12 \mathrm{a}$ & 2.43 \\
\hline Çınar-2 & 4 & $25.65 a$ & 2.70 \\
\hline Çınar-3 & 4 & $22.15 a$ & 2.33 \\
\hline Kayapınar-1 & 4 & $20.12 b$ & 2.12 \\
\hline Kayapınar-2 & 4 & $18.18 \mathrm{~b}$ & 1.91 \\
\hline Ergani & 4 & $20.14 b$ & 2.12 \\
\hline Eğil & 4 & $16.15 b$ & 1.70 \\
\hline Sur-1 & 4 & $23.25 a$ & 2.01 \\
\hline Sur-2 & 4 & $19.14 \mathrm{~b}$ & 2.01 \\
\hline Yenișehir-1 & 4 & $25.13 a$ & 2.65 \\
\hline Yenișehir-2 & 4 & $24.98 \mathrm{a}$ & 2.63 \\
\hline Yenișehir-3 & 4 & $22.16 \mathrm{a}$ & 2.33 \\
\hline
\end{tabular}

Tablo3. Tetranychus urticae popülasyonlarında GST enzim aktivitesi

\begin{tabular}{|c|c|c|c|}
\hline Popülasyon & $\mathrm{n}^{*}$ & $\begin{array}{l}\text { Spesifik aktivite } \\
\text { mOD } \text { min }^{-1} \mathrm{mg}^{-1} \\
\text { protein }\end{array}$ & $\mathrm{R} / \mathrm{S}^{* *}$ \\
\hline GSS & 4 & $3.11 c$ & - \\
\hline Bismil-1 & 4 & $6.12 \mathrm{a}$ & 1.96 \\
\hline Bismil-2 & 4 & $7.14 \mathrm{a}$ & 2.29 \\
\hline Bismil-3 & 4 & $7.78 \mathrm{a}$ & 2.50 \\
\hline Çınar-1 & 4 & $6.18 a$ & 1.98 \\
\hline Çınar-2 & 4 & $7.15 a$ & 2.29 \\
\hline Çınar-3 & 4 & $8.45 a$ & 2.71 \\
\hline Kayapınar-1 & 4 & $7.25 \mathrm{a}$ & 2.33 \\
\hline Kayapınar-2 & 4 & $4.15 b$ & 1.33 \\
\hline Ergani & 4 & $5.25 b$ & 1.68 \\
\hline Eğil & 4 & $5.56 \mathrm{~b}$ & 1.78 \\
\hline Sur-1 & 4 & $7.28 \mathrm{a}$ & 2.34 \\
\hline Sur-2 & 4 & $4.78 \mathrm{~b}$ & 1.53 \\
\hline Yenişehir-1 & 4 & $6.56 a$ & 2.10 \\
\hline Yenişehir-2 & 4 & $5.45 b$ & 1.75 \\
\hline Yenișehir-3 & 4 & $5.35 \mathrm{~b}$ & 1.72 \\
\hline
\end{tabular}

Pamuk tarlalarından toplanan ve hassas T. urticae popülasyonlarında biyokimyasal testlerle elde edilen GST enzim aktivitesi sonuçları Tablo 3'de verilmiştir.Arazi popüalsyonlarında en yüksek GST enzim aktivitesi Çınar-3 popülasyonunda $8.45 \mathrm{mOD}$ min-1 $^{-1} \mathrm{mg}^{-1}$ protein, en düşük enzim aktivitesi Kayapınar-2 popülasyonunda $4.15 \mathrm{mOD} \mathrm{min}^{-1} \mathrm{mg}^{-1}$ protein olarak bulunmuştur.Pamuk alanlarından toplanan tüm T. urticae popülasyonlarında belirlenen GST enzim aktivitesi hassas popülasyona göre yüksek bulunmuştur.

\section{Tartışma ve Sonuç}

Çalışma sonucu Diyarbakır ili pamuk üretim alanlarından toplanan T. urticae popülasyonlarında kırmızıörümcek mücadelesinde en fazla kullanılan akarisitlerden birisi olan abamectin'e karşı yüksek oranda direnç geliştiğini ortaya koymuştur.

Bioassay testleri sonuçlarına göre Diyarbakır ili pamuk alanlarından toplanan kırmızıörümcek popülasyonlarında hassas popülasyona oranla 55.03328.36 kat arasında değișen yüksek oranlarda abamectin direnci tespit edilmiştir. Arazi popülasyonlarının esteraz enzim aktiviteleri hassas popülasyona oranla 1.70-2.82 kat arasında, GST enzim aktiviteleri ise 1.33-2.71 kat arasında değişen oranlarda bulunmuștur. Pamuk üretim alanlarından toplanılan $T$. urticae popülasyonlarının tamamında hem esteraz hem de GST enzim aktivitesi hassas popülasyona göre yüksek bulunmuştur. Bu sonuçlara göre Diyarbakır ili pamuk üretim alanlarından toplanan T. urticae popülasyonarında esteraz ve GST enzim aktivitelerinin abamectin direnci ile ilișkili olduğu düşünülmektedir.

Direnç gelişimi, zararlılarla mücadelede en fazla kullanılan yöntem olan kimyasal savașımı zorlaştırdığından istenmeyen bir olgudur. Pestisit direnci kırmızıörümcekler gibi gelişme süreleri kısa ve üreme gücü yüksek olan polifag zararlılarda daha hızlı gelişmektedir. Kırmızıörümceklerin birçok pestisite direnç geliștirdiği bildirilmektedir [8]. Ülkemizde ve dünyada kırmızıörümceklerin abamectine direnç geliştirdiğine dair yapılan çalışmaların sayısı her geçen gün artmaktadır.

Stumpf ve Nauen [9], abamectin dirençli T. urticae popülasyonunda 1.6 kat esteraz ve 1.6 kat GST enzim aktivitesi belirlemişlerdir. Sato vd. [10], abamectin ile selekte edilmiş $T$. urticae popülasyonunda çapraz direnç gelișimi ve direncin stabilitesini incelemişlerdir. Abamectin' e karşı en yüksek direnç oranı 342 kat olarak bulunmuştur. Vassiliou ve Kitsis [11] Kıbrıs adasında yaptıkları çalışmada $T$. urticae'nin 5 arazi popülasyonunda abamectin, acrinathrin, fenazaquin, pirimiphosmethyl ve bifenazate direncini araştırmışlardır. Abamectin, acrinathrin ve fenazaquin için en yüksek direnç değerleri sırasıyla 3822kat, 903 kat ve 310 kat olarak bulunmuștur. Pirimiphosmethyl ve bifenazate için ise direnç oranları sırasıyla 13.3-77.4 ve 2.7-24.4 kat arasında değişen oranlarda tespit edilmiştir. Yorulmaz ve Kocaman [12] Isparta ili kesme çiçek seralarından topladıkları T. urticae popülasyonlarında abamectine karşı 43.53-246.23 
kat direnç belirlemişlerdir. Ayrıca esteraz enzim aktivitesi sonuçlarına göre abamectin direnciyle esteraz enziminin ilişkili olabileceğini bildirmișlerdir. Yalçın vd. [13] yaptıkları çalışmada $T$ urticae'nin ergin denemelerinde abamectiniçin 2.39-7.86 kat direnç bulmuşlardır. Arazi popülasyonlarının esteraz ve GST enzim aktiviteleri sirayla 7.72-10.69 mOD $\mathrm{min}^{-1} \mathrm{mg}^{-1}$ protein ve 5.92-7.56 mOD $\mathrm{min}^{-1} \mathrm{mg}^{-1}$ protein, hassas popülasyonun ise 3.83 ve $5.49 \mathrm{mOD}$ min $^{-1} \mathrm{mg}^{-1}$ protein olarak tespit edilmiştir. Çalışmamızda da literatürle benzer şekilde T. urticae popülasyonlarında abamectin direnci ve direnç ile bağlantılı olduğu düşünülen yüksek esteraz ve GST enzim aktiviteleri belirlenmiştir.

Direnç yönetimi stratejilerinin kırmızıörümceklerle mücadelede entegre mücadele programına dahil edilmesi mutlaka gereklidir. Kırmızıörümceklerde doğası gereği direnç gelişimini engellemek mümkün olmayacağından, direnç gelişimini yavaşlatıcı veya var olan direncin geri dönüşümünün sağlanacağı birtakım uygulamalar tavsiye edilmektedir. $\mathrm{Bu}$ amaçla yapılan kullanılan pestisitlerin farklı etki mekanizmasına sahip olanlarla rotasyona sokulması, farklı pestisitlerin bir arada kullanılarak rotasyona sinerjistik etki yaratılması ve ekim nöbeti gibi uygulamalarla biyolojik savaşım yöntemlerinin mücadele programina dahi ledilmesi gibi uygulamalar yapılabilmektedir [14]. Ancak bu tez çalışmasında elde edilen veriler ve literatürdeki kırmızıörümcek direnci ile ilgili yapılan çalışmalar göz önüne alındığında bu uygulamaların pratikte kullanımları yetersiz olduğu sonucuna varılmaktadır. Buradan hareketle direnç konusundaki çalışmaların yaygınlaştırılması, çeşitlendirilmesi ve özellikle üreticilerin bu konuda bilinçlendirilmesi gerektiği sonucuna varılmaktadır.

\section{Teşekkür}

Çalıșmada kırmızı örümceklerin teșhisini yapan Prof. Dr. Sultan ÇOBANOĞLU'na teșekkür ederiz. FYL2018-6056'lu Proje ile çalışmayı maddi olarak destekleyen Süleyman Demirel Üniversitesi Bilimsel Araştırma Projeleri Yönetim Birimi Başkanlığı'na teșekkür ederiz. Bu çalışma ikinci yazarın yüksek lisan tezinden oluşmaktadır.

\section{Kaynakça}

[1] Telatar, E., Türkmen, Ş., Teoman, Ö., 2002. Pamuk Borsalarında Oluşan Fiyatların Etkinliği. Dokuz Eylül Üniversitesi İktisadi İdari Bilimler Fakültesi Dergisi, 17(2), 55-74.

[2] ICAC, 2019. International Cotton Advisory Committe. https://icac.org/ (Erişim Tarihi: 01.02.2019).

[3] Bondada, B.R., Oosterhuis, D.M., Tugwell, N.P., Kim, K.S., 1995. Physiological and cytological studies of two spotted spider mite, Tetranychus urticae K., injury in cotton. Southwestern Entomologist, 20(2), 171-180.

[4] Wang, L., Wu, Y. 2007. Cross-resistance and Biochemical Mechanisms of Abamectin Resistance in the B-type Bemisia tabaci. Journal of Applied Entomology, 131, 98-103.

[5] Rauch, N., Nauen, R. 2002. Spirodiclofen Resistance Risk Assessment in Tetranychus urticae (Acari: Tetranychidae): a Biochemical Approach. Pesticide Biochemistry and Physiology, 74(2), 91-101.

[6] LeOra Software, 1987. POLO-PC: a user's guide to probit or logit analysis.

[7] Bradford, M. M. 1976. A Rapid and Sensitive Method for the Quantitation of Microgram Quantities of Protein Utilizing the Principle of Protein-dye Binding. Analytical Biochemistry, 72(1-2), 248-254

[8] Van Leeuwen, T., Vontas, J., Tsagkarakou, A., Dermauw, W., Tirry, L., 2010. Acaricide resistance mechanisms in the two-spotted spider mite Tetranychus urticae and other important Acari: a review. Insect biochemistry and molecular biology, 40(8), 563-572.

[9] Stumpf, N., Nauen, R. 2002. Biochemical Markers Linked to Abamectin Resistance in Tetranychus urticae (Acari: Tetranychidae). Pesticide Biochemistry and Physiology, 72(2), 111-121.

[10] Sato, M.E., Silva, M.Z.D., Raga, A., Souza Filho, M.F.D., 2005. Abamectin resistance in Tetranychus urticae Koch (Acari: Tetranychidae): selection, cross-resistance and stability of resistance. Neotropical Entomology, 34(6), 991-998.

[11] Vassiliou, V.A., Kitsis, P., 2013. Acaricide resistance in Tetranychus urticae (Acari: Tetranychidae) populations from Cyprus. Journal of economic entomology, 106(4), 18481854.

[12] Salman, S. Y., Kocaman, T., 2017. Tetranychus urticae Koch (Acari: Tetranychidae)'nin karanfil popülasyonlarında abamectin ve spirodiclofen'e karşı duyarlılık düzeyleri. Türkiye Entomoloji Bülteni, 7(2), 135-142.

[13] Yalçin, K., Döker, İ., Kazak, C., 2018. Acaricide resistance in Tetranychus urticae red form (Acari: Tetranychidae) collected from strawberry in southern Turkey: Bioassay and biochemical studies1. Systematic and Applied Acarology, 23(12), 2279-2288.

[14] Sparks, T. C.,Nauen, R. 2015. IRAC: Mode of Action Classification and Insecticide Resistance Management. Pesticide Biochemistry and Physiology, 121, 122-128. 